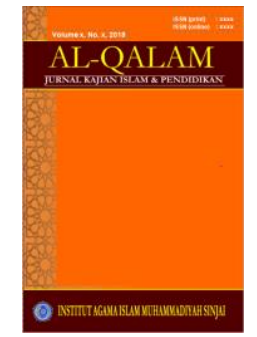

AL-QALAM

Jurnal Kajian Islam \& Pendidikan

Volume 7, No. 1, 2015

ISSN (print) : 1858-4152

ISSN (online) : 2715-5684

Homepage : http://journal.al-qalam.iaims.ac.id

\title{
GENERALISASI EMPIRIK; PROPOSISI, POSTULAT, AKSIOMA DAN TEORI
}

\author{
Oleh: Muh. Judrah*
}

$* * *$

\begin{abstract}
Abstrak
Filsafat adalah kegiatan intelektual yang secara kritis-radikal mencoba memahami hakikat sesuatu, atau sejauh yang dapat dijangkau oleh akal budi mencari sebab-sebab terdalam dari segala sesuatu dengan segala implikasinya, berdasarkan kekuatan akal budi tanpa menggantungkan diri pada otoritas manapun. Filsafat dapat dibagi ke dalam Metafisika atau Ontologi yang merenungkan hakikat hal yang ada, Epistemologi yang merenungkan hakikat pengetahuan dan landasan pengetahuan manusia, Logika yang merenungkan hakikat berpikir, Etika yang merenungkan hakikat nilai dan prilaku yang baik, dan Estetika yang merenungkan hakikat nilai keindahan. Penalaran berlangsung lewat argumen sebagai kelompok proposisi. Proposisi tersusun dari premis ke konklusi lewat generalisasi yang diperoleh dari sejumlah fenomena yang ada (generalisasi empirik), tersusun atas postulat, aksioma dan akhirnya menghasilkan sebuah teori. Hal inilah yang selanjutnya akan kami bahas dalam makalah ini.
\end{abstract}

Kata Kunci: Filsafat, Empirik, Logika, Estetika

\section{PENDAHULUAN}

\section{A. Latar Belakang}

Berbicara mengenai filsafat, maka suatu keniscayaan untuk memisahkannya dari ilmu dan ilmu pengetahuan itu sendiri. Hal ini karena filsafat adalah induk dari semua ilmu pengetahuan. Manusia dianugerahi akal pikiran sehingga menjadikannya lebih tinggi derajatnya dari makhluk ciptaan Tuhan yang lain. Dengan akal pikiran inilah manusia melakukan pengembaraan mencari hakikat hidup dan kehidupan, mencapai sebuah kebenaran atas hakikat segala sesuatunya. Karenanya dalam arti praktisnya berfilsafat adalah berpikir. Namun tidak setiap berpikir itu berfilsafat. Berfilsafat dalam hal ini adalah berpikir secara logis, rasional, sistematis, universal, bebas dan radikal.

\footnotetext{
* Dosen Tetap STAI Muhammadiyah Sinjai
} 


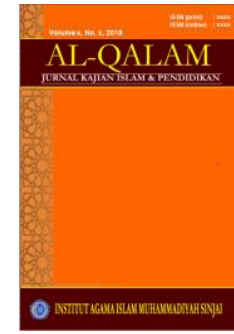

AL-QALAM

Jurnal Kajian Islam \& Pendidikan

Volume 7, No. 1, 2015

ISSN (print) : 1858-4152

ISSN (online) : 2715-5684

Homepage : http://journal.al-qalam.iaims.ac.id

Filsafat juga dapat dikatakan sebagai kegiatan intelektual yang secara kritis-radikal mencoba memahami hakikat sesuatu, atau sejauh yang dapat dijangkau oleh akal budi mencari sebab-sebab terdalam dari segala sesuatu dengan segala implikasinya, berdasarkan kekuatan akal budi tanpa menggantungkan diri pada otoritas manapun juga. ${ }^{1}$ Filsafat dapat dibagi ke dalam Metafisika atau Ontologi yang merenungkan hakikat hal yang ada, Epistemologi yang merenungkan hakikat pengetahuan dan landasan pengetahuan manusia, Logika yang merenungkan hakikat berpikir, Etika yang merenungkan hakikat nilai dan prilaku yang baik, dan Estetika yang merenungkan hakikat nilai keindahan. ${ }^{2}$

Berfilsafat adalah berfikir - di antaranya- secara logis. Ini berarti dalam berfilsafat perlu adanya penalaran yang sangat mendalam untuk mencapai kebenaran atas hakikat sesuatu. Dalam hal inilah maka logika ${ }^{3}$ sebagai suatu ilmu yang mempelajari teknik-teknik dan kaidah-kaidah penalaran yang tepat ${ }^{4}$ menjadi salah satu cabang filsafat. Yang menjadi satuan penalaran dalam logika adalah argumen. Penalaran berlangsung lewat argumen sebagai kelompok proposisi. Proposisi tersusun dari premis ke konklusi lewat generalisasi yang diperoleh dari sejumlah fenomena yang ada (generalisasi empirik), tersusun atas postulat, aksioma dan akhirnya menghasilkan sebuah teori. Hal inilah yang selanjutnya akan kami bahas dalam makalah ini.

Jadi permasalahan yang kami angkat dalam makalah ini adalah mengenai apa itu: 1 . Generalisasi Empirik, 2. Proposisi, 3. Postulat, 4. Aksioma, dan 5. Teori.

\section{PEMBAHASAN}

\section{A. Generalisasi Empirik}

\footnotetext{
${ }^{1}$ Berbagai ragam defenisi yang diberikan para ahli filsafat, namun pada hakikatnya mempunyai makna dan muara yang sama. Setidaknya itulah yang bisa kami simpulkan dari berbagai definisi yang ada.

2 Lihat, B. Arief Sidharta, Pengantar Logika: Sebuah Langkah Pertama Pengenalan Medan Telaah, (Cet. II, Bandung: PT. Refika Aditama, 2008), h. 3.

3 Istilah "logika" berasal dari kata sifat "logike" dalam bahasa Yunani. Kata bendanya adalah "logos" yang berarti perkataan sebagai manifestasi pikiran manusia. A.A. Luce -sebagaimana yang dikutip oleh B. Arief Sidharta- mengatakan bahwa "logos" berarti wacana (discourse). Jadi "pikiran' dan "kata" mempunyai hubungan erat, artinya bahwa bahasa (tutur kata) berkaitan erat dengan pikiran. Cara orang berbahasa mencerminkan caranya berpikir dan jalan pikirannya. Jadi, secara etimologikal, logika berarti ilmu yang mempelajari (jalan) pikiran yang dinyatakan atau diungkapkan dalam bahasa. Para pelopor studi logika ini adalah: zeno, kaum Sofis, Socrates, Plato, Phytagoras. Tetapi "bidan' yang melahirkan logika sebagai sebuah disiplin ilmu adalah Aristoteles, Theoprostus, dan Kaum Stoa yang karya-karyanya menghasilkan apa yang sekarang disebut Logika Klasik. Lihat: Ibid. Baca pula: Sutardjo A. Wiramihardja, Pengantar Filsafat: Sistematika Filsafat, Sejarah Filsafat, Logika dan Filsafat Ilmu (Epistemologi), Metafisika dan Filsafat Manusia, Aksiologi, (Cet. II, Bandung: PT. Refika Aditama, 2007), h. 28-31.

${ }^{4}$ http://www.harypr.com/kajian17.php., Sekilas Tentang Filsafat, 5 Oktober 2009.
} 


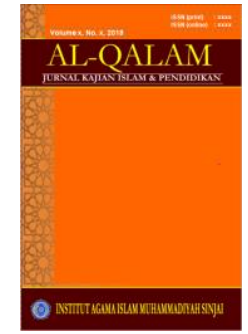

AL-QALAM

Jurnal Kajian Islam \& Pendidikan

Volume 7, No. 1, 2015

ISSN (print) : 1858-4152

ISSN (online) : 2715-5684

Homepage : http://journal.al-qalam.iaims.ac.id

\section{Pengertian Generalisasi}

Generalisasi secara etimologis berasal dari bahasa latin, Generalis yang berarti; umum, seluruh jenis, semuanya; generaliter: pada umumnya, dalam arti luas. ${ }^{5}$ Selanjutnya diartikan sebagai: 1. Pernyataan, hukum, prinsip, atau proposisi umum, 2. Kesimpulan umum, 3. Sumber primer yang menghasilkan deskripsi umum mengenai apa yang telah terjadi. ${ }^{6}$ Dalam Kamus Ilmiah Populer, generalisasi didefenisikan sebagai: 'penyamarataan, proses pemikiran yang bertujuan untuk memperoleh pendapat secara menyeluruh bagi umat manusia' ${ }^{7}$

Mundiri mendefinisikan Generalisasi sebagai "proses penalaran yang bertolak dari sejumlah fenomena individual menuju kesimpulan umum yang mengikat seluruh fenomena sejenis dengan fenomena individual yang diselidiki". ${ }^{8}$ Dengan begitu, hukum yang disimpulkan dari fenomena yang diselidiki berlaku bagi fenomena sejenis yang belum diselidiki. Oleh karena itu hukum yang dihasilkan oleh penalaran ini tidak pernah sampai pada kebenaran pasti, tetapi kebenaran kemungkinan besar (probability).

\section{Macam-Macam Generalisasi}

Berdasarkan kuantitas fenomena yang menjadi dasar penyimpulan, generalisasi dibedakan menjadi dua macam, yaitu generalisasi sempurna dan generalisasi sebagian atau generalisasi tidak sempurna. Generalisasi sempurna adalah generalisasi dimana seluruh fenomena yang menjadi dasar penyimpulan diselidiki. ${ }^{9}$ Misalnya saja jika kita memperhatikan setiap bulan dalam tahun masehi kemudian disimpulkan bahwa semua bulan masehi mempunyai hari tidak lebih dari 31, maka dalam penyimpulan ini keseluruhan fenomena yakni jumlah hari dalam setiap bulan diselidiki tanpa ada yang ditinggalkan. Generalisasi semacam ini tentu memberikan kesimpulan yang amat kuat dan tidak dapat diserang.

Generalisasi tidak sempurna yaitu generalisasi berdasarkan sebagian fenomena untuk mendapatkan kesimpulan yang berlaku bagi fenomena sejenis yang belum

\footnotetext{
${ }^{5}$ Komaruddin dan Yooke Tjuparmah S. Komaruddin, Kamus Istilah Karya Tulis Ilmiah, (Cet. IV, Jakarta: Bumi Aksara, 2000). h. 77.

${ }^{6}$ Ibid.

${ }^{7}$ Pius A. Partanto dan M. Dahlan Al-Barry, Kamus Ilmiah Populer, (tc., Surabaya: Arkola, 1994), h. 197.

8 Mundiri, Logika, (Ed. I, Jakarta: PT RajaGrafindo Persada, 2008), h. 145.

${ }^{9}$ Ibid. h. 147
} 


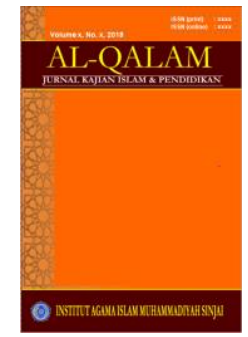

AL-QALAM

Jurnal Kajian Islam \& Pendidikan

Volume 7, No. 1, 2015

ISSN (print) : 1858-4152

ISSN (online) : 2715-5684

Homepage : http://journal.al-qalam.iaims.ac.id

diselidiki. ${ }^{10}$ Misalnya saja setelah kita menyelidiki sebagian warga Amerika Serikat bahwa mereka adalah manusia yang menganut paham liberalisme, kemudian kita simpulkan bahwa Amerika Serikat adalah bangsa liberal, maka penyimpulan ini adalah generalisasi yang tidak sempurna. Menurut para ahli, generalisasi ini disebut sebagai induksi tidak sempurna dan teknik inilah yang paling banyak digunakan dalam menyusun ilmu pengetahuan. Isaac Newton juga mendasarkan kesimpulannya pada generalisasi tidak sempurna atas teorinya yang masyhur tentang hukum gravitasi. Ilmu-ilmu kealaman semua disusun berdasarkan generalisasi tidak sempurna, demikian pula ilmu-ilmu sosial.

Menurut kami, meskipun jenis generalisasi yang kedua ini tidak menghasilkan kesimpulan sampai ke tingkat pasti -sebagaimana jenis generalisasi yang pertama- tetapi corak generalisasi yang kedua ini jauh lebih praktis dan lebih ekonomis dibanding yang pertama. Oleh karena tugas ilmu (yang disusun berdasarkan fakta-fakta observasi) tidak untuk menyajikan kebenaran mutlak melainkan kebenaran probabilitas, maka adalah keliru jika kita meyakini bahwa ilmu menyajikan hukum-hukum yang kebenarannya mutlak.

Jadi bila kita berbicara tentang generalisasi maka selalu dimaksudkan adalah generalisasi tidak sempurna, karena inilah yang sesuai dengan prinsip penyimpulan dalam ilmu pengetahuan. Meskipun generalisasi ini hanya mendasarkan pada sejumlah fenomena namun kesimpulan yang dihasilkan akan sahih dan kuat apabila didasarkan atas prosedur yang benar. Apabila generalisasi ini kemudian disertai dengan penjelasan 'mengapa' maka kebenaran yang dihasilkannya akan lebih kuat lagi.

Kita telah mengetahui bahwa tingkat keterpercayaan atau kebenaran suatu generalisasi tergantung bagaimana tingkat terpenuhinya jawaban atas evaluasi sebagaimana tersebut di atas. Bagaimanapun juga ada kecenderungan umum untuk membuat generalisasi berdasarkan fenomena yang sangat sedikit sehingga tidak mencukupi syarat untuk dibuat generalisasi. Hal ini juga bisa disebut sebagai generalisasi tergesa-gesa. ${ }^{11}$ Dalam kehidupan sehari-hari kekeliruan seperti ini sering sekali terjadi.

Untuk menguji apakah generalisasi yang dihasilkan cukup kuat untuk dipercaya, dapat kita lakukan evaluasi sebagai berikut:

1. Apakah sampel yang digunakan secara kuantitatif cukup mewakili. Memang tidak ada ukuran yang pasti berapa jumlah fenomena individual yang diperlukan untuk dapat

\footnotetext{
${ }^{10} \mathrm{lbid}$

${ }^{11}$ W. Poespoprodjo, Logika Scientifikas, (tc.,Bandung: Pustaka Grafika, 1999), h. 242.
} 


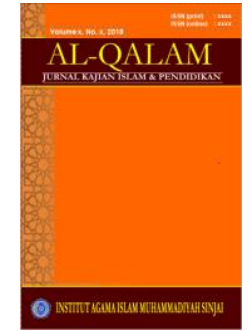

AL-QALAM

Jurnal Kajian Islam \& Pendidikan

Volume 7, No. 1, 2015

ISSN (print) : 1858-4152

ISSN (online) : 2715-5684

Homepage : http://journal.al-qalam.iaims.ac.id

menghasilkan kesimpulan yang terpercaya. Semakin banyak jumlah fenomena yang digunakan semakin kuat kesimpulan yang dihasilkan.

2. Apakah sampel yang digunakan cukup bervariasi. Semakin banyak variasi sampel, semakin kuat kesimpulan yang dihasilkan.

3. Apakah dalam generalisasi itu diperhitungkan hal-hal yang menyimpang dengan fenomena umum atau tidak. Kekecualian-kekecualian harus diperhitungkan juga, terutama jika kekecualian itu cukup besar jumlahnya. Dalam hal kekecualian cukup besar, tidak mungkin diadakan generalisasi. Bila kekecualian sedikit jumlahnya harus dirumuskan dengan hati-hati; kata-kata seperti; 'semua', 'setiap', 'selalu', 'tidak pernah', 'selamanya', dan sebagainya harus dihindari. Pemakaian kata; 'hampir seluruhnya', 'sebagian besar', 'kebanyakan'; harus didasarkan atas pertimbangan rasional yang cermat. Semakin cermat faktor-faktor pengecualian diperhitungkan, semakin kuat kesimpulan yang dihasilkan.

4. Apakah kesimpulan yang dirumuskan konsisten dengan fenomena individual. Kesimpulan yang dirumuskan haruslah merupakan konsekuensi logis dari fenomena yang dikumpulkan, tidak boleh memberikan tafsiran menyimpang dari data yang ada. ${ }^{12}$

\section{Generalisasi Empirik}

Generalisasi yang tidak disertai dengan penjelasan "mengapa" atau generalisasi yang berdasarkan fenomenanya semata-mata, itulah yang disebut Generalisasi Empirik. ${ }^{13}$ Dalam Kamus Istilah Karya Tulis Ilmiah, generalisasi empirik didefenisikan sebagai: 'suatu hukum, hipotesis, proposisi, atau tesis yang dirumuskan atas dasar pengamatan terhadap suatu kenyataan tertentu dan spesifik, faktor-faktor yang dianggap konstan (atau diasumsikan)". ${ }^{14}$ Jadi menurut kami, generalisasi empirik itu adalah suatu bentuk generalisasi (tentunya generalisasi yang tidak sempurna) yang hanya mendasarkan penyimpulannya pada fenomenanya semata-mata tanpa disertai penjelasan mengapa fenomena seperti itu berlaku.

Misalnya saja kita mempercayai generalisasi Darwin bahwa "semua kucing berbulu putih dan bermata biru adalah tuli”. Pernyataan ini didasarkan atas generalisasi yang benar

12 Lihat: Mundiri, Op. Cit., 149-150. Baca pula: R. G. Soekadijo, Logika Dasar, (tc., Jakarta: PT Gramedia, 1991), h. 135.

${ }^{13}$ Lihat; Mundiri, Op. Cit., h. 153. Bandingkan pula penjelasan ini pada: Walter L. Wallace, Metode Logika Ilmu Sosial, (tc., Jakarta: Bumi Aksara, 1994), h. 36.

${ }^{14}$ Komaruddin dan Yooke Tjuparmah S. Komaruddin, Loc. Cit. 


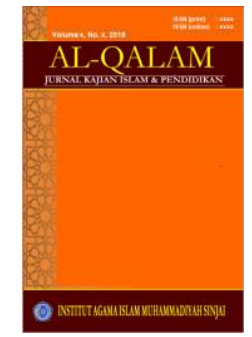

AL-QALAM

Jurnal Kajian Islam \& Pendidikan

Volume 7, No. 1, 2015

ISSN (print) : 1858-4152

ISSN (online) : 2715-5684

Homepage : http://journal.al-qalam.iaims.ac.id

dan terpercaya, sehingga kita semua mengakui kebenaran pernyataan ini. Tetapi sejauh pernyataan ini hanya mendasarkan kepada fenomenanya saja, maka merupakan generalisasi empirik. Apabila kemudian kita dapat menjelaskan mengapa kucing yang serupa itu adalah tuli, yakni menghubungkan bahwa ketiadaan pigmen pada bulu kucing dan warna matanya mengakibatkan organ pendengarannya tidak berfungsi maka generalisasi ini disebut generalisasi dengan penjelasan (explained generalization). Generalisasi ini mempunyai taraf kebenaran hampir setingkat dengan generalisasi sempurna.

Sudah diketahui bahwa penalaran yang menyimpulkan suatu konklusi yang bersifat umum dari premis-premis yang berupa proposisi empirik itu disebut generalisasi empirik. Prinsip yang menjadi penalaran generalisasi itu dapat dirumuskan demikian: Apa yang terjadi berkali-kali dalam kondisi tertentu, dapat diharapkan akan selalu terjadi apabila kondisi yang sama terpenuhi. Dua kali kita jumpai apel masam dalam kondisi keras dan hijau. Maka ketika melihat apel ketiga memenuhi kondisi keras dan hijau, kita menyimpulkan, bahwa dapat diharapkan apel itu pun masam rasanya. ${ }^{15}$ Kesimpulan itu hanya suatu harapan, suatu kepercayaan, karena seperti dikatakan di atas, konklusi penalaran induktif tidak mengandung kebenaran yang pasti, akan tetapi hanya berupa suatu probabilitas, suatu peluang.

Kebanyakan generalisasi pada kehidupan kita adalah generalisasi empirik, yang berjalan bertahun-tahun bahkan berabad-abad sampai akhirnya dapat diterangkan. Manusia telah lama mengetahui dan mereka telah menyimpulkan bahwa sebuah benda yang dilemparkan ke atas akan jatuh kembali ke bawah dan bahwa laut manapun bergelombang naik turun, tetapi baru dapat diterangkan mengapa hal itu bisa terjadi setelah Isaac Newton menemukan hukum gravitasi.

Jadi benarlah bahwa hukum alam mula-mula dirumuskan melalui generalisasi empirik kemudian setelah diketahui hubungan kausalnya, maka lahirlah generalisasi dengan penjelasan dan inilah yang melahirkan penjelasan ilmiah. ${ }^{16}$

\section{B. Proposisi}

\section{Pengertian Proposisi}

${ }^{15}$ Lihat; Surajiyo, dkk., Dasar-Dasar Logika, (tc., Jakarta: Bumi Angkasa, 2006), h. 61.

${ }^{16}$ Lihat: Mundiri, Op. Cit., h. 154-155. 


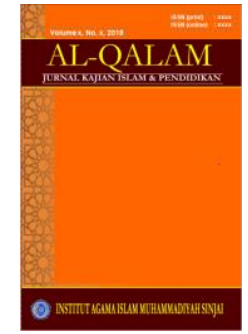

AL-QALAM

Jurnal Kajian Islam \& Pendidikan

Volume 7, No. 1, 2015

ISSN (print) : 1858-4152

ISSN (online) : 2715-5684

Homepage : http://journal.al-qalam.iaims.ac.id

Kata 'Proposisi' berasal dari bahasa Latin, proposition, yang berarti: pokok, hal menunjukkan, tema, hal menampilkan. ${ }^{17}$ Selanjutnya proposisi diartikan sebagai:

Anggapan mengenai sesuatu,2. Perumusan masalah, 3. Dalam silogisme; pangkal pertama/mayor, 4. Sesuatu yang diusulkan atau ditawarkan untuk dipertimbangkan atau diterima, 5. Suatu ungkapan dalam bahasa atau isyarat-isyarat mengenai sesuatu yang mungkin benar atau salah, 6. Suatu proyek atau situasi yang membutuhkan tindakan, 7. Suatu penuturan yang utuh, 8. Suatu ungkapan keputusan dalam kata-kata atau manifestasi keputusan. ${ }^{18}$

Proposisi merupakan unit terkecil dari pemikiran yang mengandung maksud sempurna. $^{19}$ Jika kita menganalisis suatu pemikiran, misalnya suatu buku, kita akan mendapati kesatuan pemikiran dalam buku itu, kemudian lebih khusus lagi dalam babbabnya, kemudian pada paragrafnya dan akhirnya pada unit yang tidak bisa dibagi lagi yakni yang disebut proposisi. Proposisi itu sendiri masih bisa dianalisis lagi menjadi kata-kata, tetapi kata-kata hanya menghadirkan pengertian sesuatu, bukan maksud atau pemikiran sesuatu. Semua pernyataan pikiran yang mengungkapkan keinginan dan kehendak tidak dapat dinilai benar dan salahnya bukanlah proposisi. ${ }^{20}$

Proposisi adalah pernyataan dalam bentuk kalimat yang dapat dinilai benar dan salahnya. Dengan kata lain, proposisi adalah pernyataan untuk mengiyakan atau menyangkal sesuatu yang dapat diujicoba. ${ }^{21}$ Jadi pada hakikatnya proposisi adalah pendirian atau pendapat tentang sesuatu hal, yakni pendirian atau pendapat tentang hubungan antara dua hal. Terhadap proposisi dapat dikenakan penilaian benar atau salah, karena pendirian seseorang tentang hubungan antara dua hal itu dalam kenyataan dapat benar dapat juga salah.

Jadi setidaknya proposisi terdiri dari pokok yang dibicarakan (subjek), apa yang disangkal atau diiyakan (predikat), dan hubungan yang sifatnya menyatukan atau memisahkan (copula) dan quantifier, banyaknya satuan yang diikat oleh term subyek.. ${ }^{22}$ Apa yang diajukan sebagai pendirian tentang hubungan antara dua hal tersebut dirumuskan dalam

\footnotetext{
${ }^{17}$ Komaruddin dan Yooke Tjuparmah S. komaruddin, Op. Cit., h. 208.

${ }^{18}$ Ibid.

${ }^{19}$ Mundiri, Op. Cit., h. 54

${ }^{20}$ Lihat, Ibid.

${ }^{21}$ http://www.harypr.com/kajian17,php, Sekilas Tentang Filsafat, 5 oktober 2009.

22 Aristoteles memandang bahwa setidaknya proposisi terdiri atas tiga bagian; subjek, predikat dan
} copula. Bambang Q. Anees dan Radea Juli A. Hambali, Filsafat Untuk Umum, (Cet. I, Jakarta: Kencana, 2003), h. 202 . 


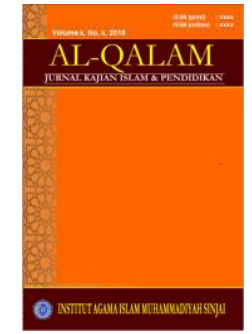

AL-QALAM

Jurnal Kajian Islam \& Pendidikan

Volume 7, No. 1, 2015

ISSN (print) : 1858-4152

ISSN (online) : 2715-5684

Homepage : http://journal.al-qalam.iaims.ac.id

sebuah kalimat. Jadi setiap proposisi berupa kalimat, tetapi tidak semua kalimat adalah proposisi. Hanya kalimat deklaratif yang disebut proposisi. Karenanya walaupun proposisi itu harus dirumuskan dengan sebuah kalimat, namun proposisi itu tidak boleh begitu saja diidentikkan dengan kalimat. Sebab, sebuah proposisi tertentu dapat diungkapkan dengan kalimat yang berbeda-beda. Artinya, beberapa kalimat yang berbeda, yakni rangkaian katakata yang digunakan tidak sama, dapat mengungkapkan sebuah proposisi (hubungan antara dua hal) yang sama. ${ }^{23}$

Sebagaimana disebutkan di atas, bahwa hanya kalimat deklaratif yang dinamakan proposisi. Suatu kalimat deklaratif mengekspresikan suatu penegasan, entah secara afirmatif entah secara negatif. Benar atau salahnya isi penegasan itu dapat diujicoba atau dibuktikan. Benar pada dasarnya adalah persesuaian antara pikiran dan kenyataan. ${ }^{24}$ Pernyataan " rusa adalah seekor hewan" adalah benar karena kenyataannya memang seperti itu. Ukuran kebenaran yang kedua adalah adanya persesuaian atau tidak adanya pertentangan dalam pernyataan tersebut. ${ }^{25}$ Misalnya pernyataan " Hamidah adalah seorang jujur yang suka menipu". Pernyataan tersebut tentu saja salah karena antara "jujur' dan "suka menipu" bertentangan.

\section{Macam-Macam Proposisi}

Dalam logika dikenal adanya dua macam proposisi menurut sumbernya, yaitu proposisi analitik dan proposisi sintetik. Proposisi analitik adalah proposisi yang predikatnya mempunyai pengertian yang sudah terkandung pada subyeknya. Contoh; "sirsak adalah buahbuahan". Kata "buah-buahan" pengertiannya sudah terkandung pada subyek "sirsak". Jadi tidak mendatangkan pengetahuan baru. Untuk menilai benar tidaknya kita lihat ada tidaknya pertentangan dalam diri pernyataan itu. Proposisi analitik di sebut juga proposisi a priori. $^{26}$

Proposisi sintetik adalah proposisi yang predikatnya mempunyai pengertian yang bukan menjadi keharusan bagi subyeknya. Contoh: "sirsak itu manis". Kata "manis" pengertiannya belum terkandung pada subyeknya yaitu "sirsak'. Ini mendatangkan pengetahuan baru yang didapat melalui pengalaman. Proposisi sintetik adalah lukisan dari

Ibid. h. 55

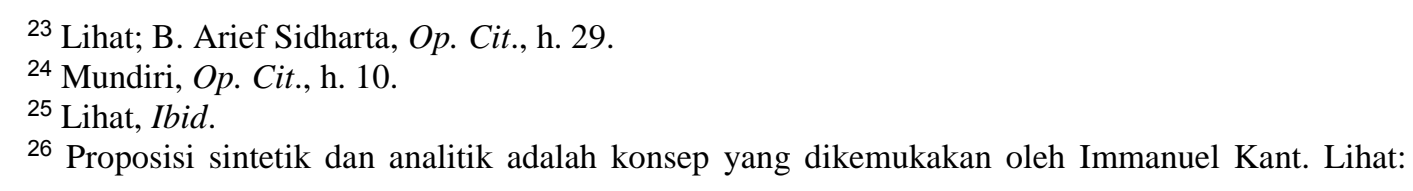


kenyataan empirik maka untuk menguji benar salahnya diukur berdasarkan sesuai tidaknya dengan kenyataan empiriknya. proposisi ini disebut juga proposisi a posteriori. $^{27}$

Namun secara umum proposisi dapat dibagi atas: proposisi kategoris, proposisi hipotetis dan proposisi modalitas. ${ }^{28}$

Proposisi kategorik adalah proposisi yang mengandung pernyataan tanpa adanya syarat. Kualitas proposisi kategorik bisa afirmatif ataupun negatif dengan melihat copulanya. Dan kuantitasnya bisa universal, partikular atau singular terrgantung pada quantifiernya,. ${ }^{29}$

Proposisi hipotetis mengekspresikan redaksi ketergantungan antara dua gagasan, baik dalam bentuk oposisi, maupun dalam bentuk kemiripan. Di dalam proposisi hipotetis terdapat afirmai atau negasi yang bersifat kondisional. Dengan perkataan lain, di dalam proposisi hipotetis term predikatnya menerangkan term subjek dengan suatu syarat. proposisi ini ada tiga macam, yakni pertama, proposisi kondisional yakni proposisi yang menyatakan suatu kondisi atau hubungan ketergantungan antara dua proposisi. Hubungan tersebut menunjukkan bahwa proposisi yang satu pasti mengikuti proposisi yang lainnya karena adanya kondisi tertentu. Kedua, proposisi disjungtif, yakni proposisi yang mengandung pilihan antara dua kemungkinan. Dan ketiga, proposisi konjungtif, yakni proposisi yang memiliki dua predikat yang kontraris yang tidak mungkin sama-sama memiliki kebenaran pada saat yang bersamaan.

Proposisi modalitas adalah proposisi yang didalamnya terdapat kata-kata yang menyatakan tingkat-tingkat kepastian, seperti kata-kata 'tentu', 'niscaya', 'mungkin', 'tidak tentu', 'tidak niscaya', 'tidak mungkin', 'pasti', 'mustahil'. Proposisi modalitas tidak sekedar menyatakan bahwa predikat merupakan bagian dari subjek atau tidak merupakan bagian dari subjek, melainkan juga menyatakan bagaimana predikat itu menjadi bagian atau tidak menjadi bagian dari subjek. Proposisi modalitas terbagi atas empat yaitu, pertama, proposisi modalitas mutlak, yakni proposisi yang di dalamnya predikat tidak dapat berfungsi lain, kecuali menjadi bagian dari subjek. Kedua, proposisi modalitas kontingen, yakni proposisi yang mengekspresikan suatu kebenaran yang bersifat semnetara (kontingen), ketiga, proposisi modalitas yang mungkin, yakni prorposisi yang mengekspresikan suatu kemungkinan, yaitu suatu identitas yang mungkin terjadi antara subjek dan predikat,

${ }^{27}$ Lihat, Ibid, h. 55-56.

${ }^{28}$ Rafael Raga Maran, Pengantar Logika, (tc., Jakarta: PT.Grasindo, 2007) h. 65. Bandingkan pula pembagian proposisi ini pada: Mundiri, Op. cit, h. 56.

${ }^{29}$ Untuk lebih jelasnya baca: Ibid., h. 56 - 69 


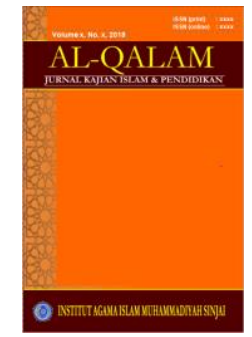

AL-QALAM

Jurnal Kajian Islam \& Pendidikan

Volume 7, No. 1, 2015

ISSN (print) : 1858-4152

ISSN (online) : 2715-5684

Homepage : http://journal.al-qalam.iaims.ac.id

keempat, proposisi modalitas tidak mungkin, yakni proposisi yang menyatakan sesuatu yang tidak dapat terjadi. ${ }^{30}$

\section{Postulat}

\section{Pengertian Postulat}

Postulat berasal dari bahasa Latin, Postulo (menganggap, menghendaki); Postulatum (tuntutan, keinginan, anggapan). ${ }^{31}$ Selanjutnya diartikan: 1. Suatu hipotesis yang dikembangkan sebagai dasar esensial suatu sistem berpikir atau premise dari serentetan penalaran, 2. Dalil yang dianggap benar, kendatipun kebenarannya tidak dapat dibuktikan, 3. Pengandaian yang keabsahannya tidak dapat dibuktikan, namun harus diandaikan supaya dapat memahami gejala dalam rangka kesatuan berpikir, 4. Dalam matematika, aksioma. ${ }^{32}$

Biasanya setiap pernyataan tentang suatu fenomena atau fakta harus diuji kebenarannya, apakah hal tersebut benar ataukah salah sebelum kita meyakininya. Namun adakalanya beberapa ide atau fakta, harus diterima sebagai postulat, yaitu kita terima atau kita yakini sebagaimana adanya.

Suatu postulat adalah suatu asumsi yang diperlukan. Ia adalah suatu pengandaian yang harus diterima untuk menjelaskan suatu fenomena natural. ${ }^{33}$ Postulat bekerja dengan baik pada hukum-hukum atau aturan-aturan dimana postulat atau aksioma di gunakan. Misalnya postulat Einstenin mengenai relativitas yang menyatakan kecepatan cahaya di ruang hampa adalah sekian meter perdetik dan sama untuk setiap pengamatan. Postulat itu digunakan dan diciptakan menjadi pondasi pokok dari proses relativitas yang sampai sekarang belum tergoyahkan. Postulat ini menjadi terpercaya memiliki kebenaran karena adanya kredibilitas dalam bentuk pembuktian secara filsifkasional dalam dunia fisika. ${ }^{34}$

\section{Prinsip-Prinsip Postulat}

Adapun prinsip daripada postulat adalah:

\footnotetext{
${ }^{30}$ Lebih jelasnya, baca : Rafael Raga Maran, Op. Cit., h. 76-78.

${ }^{31}$ Komaruddin dan Yooke Tjuparmah S. Komaruddin, Op. Cit., h. 199.

${ }^{32}$ Ibid. Lihat pula: Burhanuddin Salam, Pengantar Filsafat, (Ed. I, Cet. VI, Jakarta: Bumi Aksara, 2005), h. 35 .

${ }^{33}$ Rafael Raga Maran, Op. Cit., h. 140.

${ }^{34}$ Lihat; Ibid.
} 


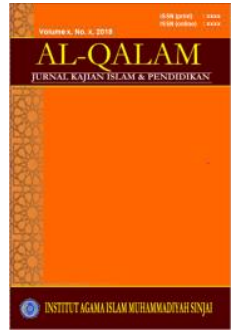

AL-QALAM

Jurnal Kajian Islam \& Pendidikan

Volume 7, No. 1, 2015

ISSN (print) : 1858-4152

ISSN (online) : 2715-5684

Homepage : http://journal.al-qalam.iaims.ac.id

1. Prinsip kausalitas, merupakan suatu kepercayaan bahwa setiap kejadian mempunyai sebab, olehnya itu dalam keadaan yang sama, sebab yang sama, selalu menghasilkan akibat yang sama.

2. Prinsip ranalan yang sama, menyatakan bahwa sekumpulan kejadian akan menunjukkan sejumlah hubungan atau antar hubungan di masa depan sebagaimana telah ditunjukkan di masa lampau atau sebagaimana ditunjukkan pada masa sekarang.

3. Prinsip objektif, menuntut si penyelidik untuk tidak berbuat berat sebelah sehubungan dengan data yang sedang ia hadapi. Faktanya harus dapat dicoba sedemikian rupa dalam cara-cara yang sama. Maksudnya ialah menghilangkan semua subjektifitas dan unsur pribadi sejauh mungkin dan sedapat mungkin untuk memusatkan perhatian terhadap objek penelitian tersebut.

4. Prinsip empirisme, memungkinkan bagi peneliti untuk mengasumsi bahwa rasa impresinya itu benar, dan tes kebenaran merupakan suatu tuntutan ke arah fakta yang telah teruji. Mengetahui adalah akibat dari observasi, pengalaman dan percobaan. Maksudnya di sini -menurut kami- bahwa postulat itu teruji kebenarannya melalui pengalaman pengalaman.

5. Prinsip parsimony (penghematan), menyarankan bahwa untuk hal-hal yang sama, seseorang akan membuat penjelasan yang sederhana sebagai suatu pernyataan yang sah. Seorang filosof Inggris abad ke-14 bernama William Occan menyatakan, "kesatuan itu jangan diperbanyak di luar kebutuhannya"35

6. Prinsip isolasi atau pengasingan, meminta agar supaya fenomena yang akan diselidiki itu harus dipisahkan sehingga dapat diteliti tersendiri.

7. Prinsip kontrol (pengawasan), mengutamakan pentingnya pengawasan terutama pada taraf eksperimen. Jika tidak, maka akan banyak unsur-unsur yang akan menyimpan dalam waktu yang sama, dimana eksperimen itu tidak dapat diulang dengan cara yang sama. Seandainya berubah sementara eksperimen itu sedang berlangsung, hasilnyapun mungkin akan tidak sempurna.

8. Prinsip pengukuran yang tepat, menuntut supaya hasil-hasilnya nanti dapat dinyatakan dalam bentuk kuantitatif atau dalam istilah-istilah matematis. Hal ini terutama menjadi tujuan akhir daripada penelitian ilmu alam. ${ }^{36}$

\footnotetext{
${ }^{35}$ Prinsip ini dikenal pula dengan istilah 'Pisau Occan' . Burhanuddin Salam, Op. Cit., h. 35.

${ }^{36}$ Lihat; Ibid., h. 35-36.
} 


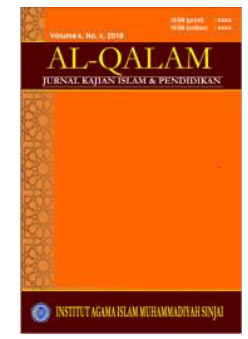

AL-QALAM

Jurnal Kajian Islam \& Pendidikan

Volume 7, No. 1, 2015

ISSN (print) : 1858-4152

ISSN (online) : 2715-5684

Homepage : http://journal.al-qalam.iaims.ac.id

Dalam ilmu-ilmu alam, atau anorganik, prinsip-prinsip postulat dan kondisi-kondisi yang tersusun di atas dapat dipenuhi secara memadai. Kita dapat mengisolasinya, mengontrolnya dan mengukurnya dengan derajat keberhasilan yang tinggi. Tetapi seandainya kita tiba pada masalah kepada makhluk-makhluk yang hidup terutama pada manusia dan masyarakat manusia, maka kondisi-kondisi yang baru dan sulit akan kita temukan, kita tidak dapat mengisolasi dan mengontrol kehidupan pada taraf-taraf tertinggi tanpa mengubah sifat/isi yang sedang dipelajarinya. Coba pisahkanlah manusia dari masyarakatnya.

\section{Aksioma}

Aksioma berasal dari bahasa Yunani axioma, yang berarti dianggap berharga atau sesuai atau dianggap terbukti dengan sendirinya. Kata ini berasal dari axioein (dianggap berharga), axisios (yang berharga). ${ }^{37}$ Dalam bahasa Inggris disebut axiom, dalam bahasa Perancis, axiome, suatu pernyataan atau dalil yang dianggap sebagai kebenaran yang terbukti sendiri; suatu dalil (proposisi) yang tidak memerlukan pembuktian atas kebenarannya, dan juga tidak dapat disimpulkan dari teori atau dalil yang lain. Sebagai suatu pernyataan yang tidak memerlukan pembuktian, maka aksioma bertindak sebagai premis untuk banyak argumen, tetapi sebagai konklusi sama sekali tidak. ${ }^{38}$ Filosop Yunani mengartikan suatu aksioma sebagai suatu pernyataan yang bisa dilihat kebenarannya tanpa perlu adanya bukti. Kata aksioma juga dimengerti dalam matematika. Akan tetapi aksioma dalam matematika bukan berarti proposisi yang terbukti dangan sendirinya melainkan dengan titik awal dari sistem logika.. Suatu aksioma adalah basis dari sistem logika formal yang bersama-sama dengan aturan infrensi mendefinisikan logika ${ }^{39}$.

Aksioma atau postulat, yaitu pernyataan yang diasumsikan benar tanpa perlu dibuktikan. Berbeda dengan teori yang bisa dibuktikan -bahkan harus dibuktikan- dengan menggunakan induksi, aksioma tidak perlu dibuktikan. Misalnya sebuah aksioma yang menyatakan "manusia adalah makhluk sosial" Berangkat dengan aksioma tersebut, bisa disusun peraturan yang mengatur hubungan antara manusia. Meski tiap daerah memiliki kebiasaannya masing-masing, namun dengan adanya aksioma universal, maka bisa dibuat transformasi-transformasi yang menyebabkan satu budaya bisa berelasi dengan budaya lainnya. Sebagai ilustrasi adalah penggunaan satuan pada temperatur. Dengan adanya

\footnotetext{
${ }^{37}$ www.aksioma.com , Aksioma, tgl 5 oktober 2009.

38 Lihat: Komaruddin dan Yooke Tjuparmah S. Komaruddin, Op. Cit., h. 12.

${ }^{39}$ www.aksioma.com , Aksioma, tgl 5 oktober 2009.
} 


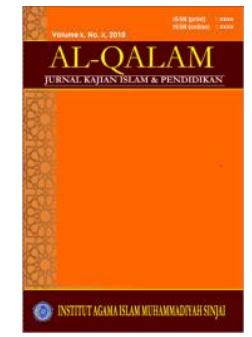

AL-QALAM

Jurnal Kajian Islam \& Pendidikan

Volume 7, No. 1, 2015

ISSN (print) : 1858-4152

ISSN (online) : 2715-5684

Homepage : http://journal.al-qalam.iaims.ac.id

kesepakatan, seseorang yang menggunakan satuan Celcius dapat mentransformasikannya menjadi Kelvin. ${ }^{40}$

Contoh lainnya, misalnya sebuah aksioma yang menyatakan; 'manusia tidak dapat tidak berkomunikasi'. Pernyataan ini terbuktikan dengan sendirinya oleh karena memang manusia pasti berkomunikasi meskipun hanya dengan dirinya sendiri. Atau aksioma yang menyatakan: 'komunikasi ada di mana-mana dan sangat potensial dalam masyarakat'. Pernyataan ini dapat dijelaskan bahwa komunikasi memasuki setiap unsur dalam masyarakat; dengan komunikasi, sikap dan nilai-nilai kehidupan dapat bergeser atau bahkan berubah sama sekali; komunikasi adalah penyebab utama dari setiap perubahan yang terjadi di masyarakat.

Jadi aksioma di sini -menurut kami- adalah suatu pernyataan yang eviden (jelas, terang, nyata) sehingga tidak perlu dibuktikan kebenarannya. Seperti pernyataan 'Islam adalah rahmat bagi seluruh alam semesta' sudah menjadi suatu aksioma bagi umat Islam, meskipun mungkin sebagian orang membantahnya. Dalam hal ini aksioma kadang diidentikkan dengan postulat, akan tetapi menurut kami postulat meskipun juga merupakan pernyataan yang harus diterima sebagaimana adanya karena diasumsikan benar, namun ia tidak eviden sehingga menungkinkan untuk adanya pembuktian, meskipun mungkin pada akhirnya tidak dapat dibuktikan sehingga berakhir pada suatu kepercayaan atau keyakinan saja.

\section{E. Teori}

\section{Pengertian Teori}

Kata 'teori' berasal dari bahasa Yunani, theoria; dalil, ajaran atau paham (pandangan) tentang sesuatu berdasarkan kekuatan akal (rasio); patokan dasar atau garis-garis dasar sains dan ilmu pengetahuan; pedoman praktek. ${ }^{41}$ Selanjutnya dalam Kamus istilah karya Tulis Ilmiah, 'teori' diartikan sebagai: 1. Pemikiran yang abstrak; spekulasi, 2. Prinsip-prinsip umum atau abstrak mengenai kumpulan fakta, ilmu pengetahuan atau seni; 3. Perkiraan, dugaan, atau pengandaian; 4. Suatu sistem yang terdiri atas dalil-dalil dan hipotesis dengan dasar-dasar tertentu; 5. Prinsip umum yang ilmiah atau rasional, atau kumpulan prinsip untuk menjelaskan gejala; 6 . Suatu hipotesis yang dipergunakan untuk argumen atau investigasi. ${ }^{42}$

\footnotetext{
${ }^{40}$ Lihat :Ibid.

${ }^{41}$ Pius A. Partanto dan M. Dahlan Al Barry, Op. Cit., h. 746.

42 Komaruddin dan Yooke Tjuparmah S. Komaruddin, Op. Cit., h. 270.
} 


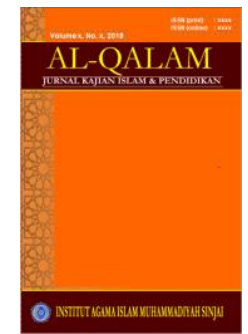

AL-QALAM

Jurnal Kajian Islam \& Pendidikan

Volume 7, No. 1, 2015

ISSN (print) : 1858-4152

ISSN (online) : 2715-5684

Homepage : http://journal.al-qalam.iaims.ac.id

Pernyataan teori umumnya hanya diterima secara "sementara" dan bukan merupakan pernyataan akhir yang konklusif. Hal ini mengindikasikan bahwa teori berasal dari penarikan kesimpulan yang memiliki potensi kesalahan, berbeda dengan penarikan kesimpulan pada pembuktian matematika. Dalam ilmu pengetahuan, teori berarti model atau kerangka pikiran yang menjelaskan fenomena alami atau fenomena sosial tertentu. Teori dirumuskan, dikembangkan, dan dievaluasi menurut metode ilmiah. Teori juga merupakan suatu hipotesis yang telah terbukti kebenarannya. Manusia membangun teori untuk menjelaskan, meramalkan, dan menguasai fenomena tertentu. Sering kali, teori dipandang sebagai suatu model atas kenyataan (misalnya: apabila kucing mengeong berarti minta makan). Sebuah teori membentuk generalisasi atas banyak observasi dan terdiri atas kumpulan ide yang koheren dan saling berkaitan. Istilah teoritis dapat digunakan untuk menjelaskan sesuatu yang diramalkan oleh suatu teori namun belum pernah terobservasi. ${ }^{43}$ Jadi teori adalah suatu pemikiran yang berupa prinsip umum yang ilmiah atau rasional tentang suatu fakta yang telah teruji kebenarannya meskipun kebenarannya tidak bersifat mutlak.

Dalam kehidupan sehari-hari kita sering mendengar ucapan; "itu betul dalam teori, tetapi tidak dapat dilaksanakan dalam praktek". Terhadap ucapan seperti ini dan yang serupa, kita hanya cukup dengan menjawab secara sederhana bahwa apabila tidak dapat dilaksanakan dalam praktek, maka berarti itu bukan teori yang benar. Teori merupakan analisis hubungan antara fakta yang satu dengan fakta yang lain pada sekumpulan fakta-fakta, ${ }^{44}$ sebab teori itu tidak lain adalah interpretasi dari fakta-fakta. ${ }^{45}$.jadi sesungguhnya tidak ada perbedaan yang nyata antara teori dengan fakta, karena setiap teori yang benar adalah merupakan pernyataan suatu fakta dalam hubungannya dengan fakta yang lain.

\section{Macam-Macam Teori}

Ada dua macam teori, teori umum dan teori khusus. Teori umum adalah suatu pernyataan apabila ia benar maka ia benar secara universal. Ia berlaku bagi semua waktu, semua tempat, dan semua keadaan serta semua permasalahan dalam 'kelas' yang dinyatakannya. Pernyataan seperti: "Perjalanan kebudayaan itu melalui tahapan tumbuh, berkembang, mencapai puncak kejayaannya, mundur dan akhirnya runtuh" dan "Semua yang

\footnotetext{
43 http://id.wikipedia.org/wiki/teori\#cite note-0, 2 oktober 2009.

${ }^{44}$ Ibid.

${ }^{45}$ Lihat; Mundiri, Op. Cit., h. 197.
} 


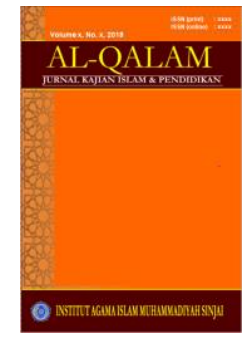

AL-QALAM

Jurnal Kajian Islam \& Pendidikan

Volume 7, No. 1, 2015

ISSN (print) : 1858-4152

ISSN (online) : 2715-5684

Homepage : http://journal.al-qalam.iaims.ac.id

kita dapati sekarang ini merupakan perkembangan yang lebih sempurna dari keadaan yang mendahuluinya", adalah merupakan teori - teori umum.

Teori khusus adalah teori yang berkaitan dengan sejumlah fakta-fakta partikular tertentu. Ia berusaha untuk menjelaskan fakta-fakta itu dalam hubungannya yang satu dengan lainnya. Ia harus sesuai dengan fakta-faktanya yang diketahuinya, tetapi juga harus berhasil mengidentifikasikan beberapa fakta atau sejumlah fakta yang selama itu belum diketahui. ${ }^{46}$ Misalnya bila seorang dokter setelah memeriksa seorang pasien ia menetapkan bahwa pasiennya menderita sakit ini dan untuk mengobatinya dengan cara begini, maka ia membuat teori yang bersifat khusus.

Setiap teori selalu bermula dari hipotesis, keduanya tidak ada perbedaan prinsip kecuali hanya graduasi saja. Hipotesis juga merupakan interpretasi dari fakta. Ia juga disusun berdasarkan fakta, tetapi kebenarannya belum diuji, sedangkan teori kebenarannya telah teruji. Oleh karena itulah maka dalam arti kasar, teori mencakup juga hipotesis.

Teori yang telah kita terima dapat kita gunakan untuk penelaahan selanjutnya, yaitu sebagai dasar berpikir (premis) dalam usaha kita menjelaskan berbagai gejala lainnya. Demikian selanjutnya maka proses kegiatan ilmiah mulai lagi melalui tahapan yang telah disebut dan setelah ditemukan teori baru lagi, maka teori baru ini juga menjadi dasar bagi pengembangan ilmu selanjutnya, demikian seterusnya, perkembangan ilmu pengetahuan itu berproses dari teori ke teori. Jadi teori itu merupakan sumber bagi kerangka penalaran dalam penyusunan hipotesis. ${ }^{47}$

Jadi menurut kami, teori menggambarkan keteraturan atau hubungan dari gejalagejala yang tidak berubah di bawah kondisi-kondisi tertentu tanpa kekecualian dalam kebenarannya. Pada awalnya, teori tersebut dirumuskan sebagai suatu hipotesis (pradalil). Sesudah melalui pemeriksaan dan pengujian oleh data yang sahih dan implikasi logika ternyata benar, maka hipotesis itu menjadi teori atau tesis. Suatu dalil dikatakan sah bilamana kebenaran dan kesimpulan benar-benar merupakan konsekuensi yang tidak dapat dihindarkan dari kebenaran hipotesis.

\footnotetext{
${ }^{46}$ Mundiri, Op. Cit., h. 198-199.

${ }^{47}$ Lihat: Ibid, h. 206.
} 


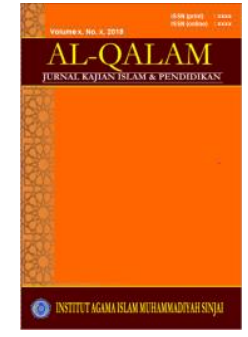

AL-QALAM

Jurnal Kajian Islam \& Pendidikan

Volume 7, No. 1, 2015

ISSN (print) : 1858-4152

ISSN (online) : 2715-5684

Homepage : http://journal.al-qalam.iaims.ac.id

\section{PENUTUP}

\section{Kesimpulan}

Dari uraian di atas, dapat kami simpulkan bahwa:

1. Generalisasi empirik adalah proses penalaran yang bertolak dari sejumlah fenomena individual menuju kesimpulan umum yang mengikat seluruh fenomena sejenis dengan fenomena individual yang diselidiki dan hukum yang dihasilkan oleh penalaran ini tidak pernah sampai pada kebenaran pasti, tetapi kebenaran kemungkinan besar (probability). Tingkat keterpercayaan atau kebenarannya tergantung bagaimana tingkat terpenuhinya jawaban atas evaluasi yang dilakukan.

2. Proposisi adalah pendirian atau pendapat tentang sesuatu hal, yakni pendirian atau pendapat tentang hubungan antara dua hal, yang dapat dinilai benar atau salah, karena pendirian seseorang tentang hubungan antara dua hal itu dalam kenyataan dapat benar dapat juga salah. Sebuah proposisi sebagai sebuah pernyataan setidaknya terdiri atas subjek, predikat, copula dan quantifier. Dilihat dari sumbernya proposisi terbagi atas proposisi analitik dan sintetik. Namun secara umum proposisi terbagi tiga yakni proposisi kategorik, proposisi hipotetik dan proposisi modalitas. Proposisi hipotetik terbagi lagi atas; proposisi kondisional, disjungtif dan konjungtif. Sedangkan proposisi modalitas terbagi atas; proposisi modalitas mutlak, kontingen dan proposisi modalitas yang mungkin.

3. Postulat adalah pernyataan yang harus diterima apa adanya karena diaumsikan benar tanpa adanya bukti. Adapun prinsip daripada postulat adalah: Prinsip kausalitas, ramalan yang sama, objektif, empirisme, parsimony (penghematan), isolasi atau pengasingan, kontrol (pengawasan), pengukuran yang tepat. Prinsip dan konidisi ini hanya bisa dilakukan secara memadai pada ilmu-ilmu alam atau anorganik.

4. Aksioma adalah suatu dalil atau pernyataan yang diyakini kebenarannya karena terbukti dengan sendirinya, karenanya tidak perlu adanya pembuktian untuk menguji kebenarannya. Meskipun aksioma ini diidentikan dengan postulat, akan tetapi aksioma di sini merupakan pernyataan yang sifatnya eviden sedangkan postulat tidak eviden, meskipun keduanya sama-sama suatu pernyataan yang diasumsikan benar tanpa adanya bukti.

5. Teori adalah suatu pemikiran yang berupa prinsip umum yang ilmiah atau rasional tentang suatu fakta yang telah teruji kebenarannya meskipun kebenarannya tidak bersifat 


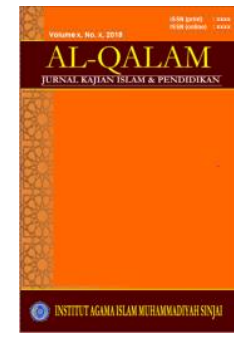

AL-QALAM

Jurnal Kajian Islam \& Pendidikan

Volume 7, No. 1, 2015

ISSN (print) : 1858-4152

ISSN (online) : 2715-5684

Homepage : http://journal.al-qalam.iaims.ac.id

mutlak.Teori ada dua macam yakni teori umum yakni suatu pernyataan apabila ia benar maka ia benar secara universal. Dan teori khusus yakni teori yang berkaitan dengan sejumlah fakta-fakta partikular tertentu.

\section{DAFTAR PUSTAKA}

Anees, Bambang Q. dan Radea Juli A. Hambali, Filsafat Untuk Umum, Cet. I, Jakarta: Kencana, 2003.

Baihaqi A.K., Ilmu Mantiq. tc., Jakarta: Radar Jaya Offset, 2007.

Komaruddin dan Dra. Yooke Tjuparmah S. Komaruddin,M.Pd., Kamus Istilah Karya Tulis Ilmiah, Cet. IV, Jakarta: Bumi Aksara, 2000.

Maran, Rafael Raga, Pengantar Logika, tc., Jakarta: PT.Grasindo, 2007.

Mundiri, Logika, Ed. I, Jakarta: PT RajaGrafindo Persada, 2008.

Partanto, Pius A. dan M. Dahlan Al-Barry, Kamus Ilmiah Populer, tc., Surabaya: Arkola, 1994.

Poespoprodjo, W., Logika Scientifikas, tc.,Bandung: Pustaka Grafika, 1999.

Salam, Burhanuddin, Pengantar Filsafat, Ed. I, Cet. VI, Jakarta: Bumi Aksara, 2005.

Sidharta, B. Arief, Pengantar Logika: Sebuah langkah Pertama Pengenalan Medan Telaah, Cet. II, Bandung: PT. Refika Aditama, 2008.

Soekadijo, R. G., Logika Dasar, tc., Jakarta: PT Gramedia, 1991.

Surajiyo, dkk., Dasar-Dasar Logika, tc., Jakarta: Bumi Angkasa, 2006.

Wallace, Walter L., Metode Logika Ilmu Sosial, tc., Jakarta: Bumi Aksara, 1994.

Wiramihardja, Sutardjo A., Pengantar Filsafat: Sistematika Filsafat, Sejarah Filsafat, Logika dan Filsafat Ilmu (Epistemologi), Metafisika dan Filsafat Manusia, Aksiologi, Cet. II, Bandung: PT. Refika Aditama, 2007.

http://id.wikipedia.org/wiki/teori\#cite_note-0, 2 oktober 2009.

http://www.harypr.com/kajian17,php, Sekilas Tentang Filsafat, 5 oktober 2009.

www.aksioma.com, Aksioma, tgl 5 oktober 2009. 